\title{
Chest Wall Fibromatosis
}

National Cancer Institute

\section{Source}

National Cancer Institute. Chest Wall Fibromatosis. NCI Thesaurus. Code C6713.

An extraabdominal fibromatosis arising from the soft tissue of the chest wall. It is characterized by the presence of elong ated spindle-shaped fibroblasts, collagenous stroma formation, and an infiltrative growth pattern. 